\title{
Drifting between passive and anticausative. True and alleged accent shifts in the history of Vedic -ya-presents
}

\begin{abstract}
This paper focuses on the system of the Vedic present formations with the suffix -ya- and middle inflexion, paying special attention to the attested accent patterns. On the basis of a study of the paradigmatic and syntactic features of this verbal formation we can conclude that the traditional analysis of some members of this class in terms of the passive/nonpassive (anticausative) opposition is inadequate. I will offer a short overview of the history of this class, concentrating, in particular, on several accent shifts which account for a number of exceptions to the general correlation between the semantics and accent placement (passives: accent on the suffix vs. non-passives: accent on the root). Some of these shifts can be dated to the prehistoric (Common Indo-Aryan?) period (cf. suffix accentuation in such non-passives as mriyáte 'dies'), while some others must be features of certain Vedic dialects, dating to the period after the split of Common Indo-Aryan.
\end{abstract}

Keywords: Sanskrit, Vedic, Rgveda, Atharvaveda, Yajurveda, Indo-European, passive, anticausative, middle voice, accentuation, accent shift.

\section{Passive, reflexive, anticausative: preliminary remarks and definitions}

The distinguishing between closely related intransitive derivations, such as passive, reflexive, anticausative (decausative), is one of the most intricate semantic and syntactic issues in languages with polysemous intransitive markers. Both anticausative and passive derivations entail the promotion of the initial direct object (= Patient) and the demotion of the initial subject (= Agent). This common syntactic feature accounts for their similar morphological marking in many languages (see e.g. Comrie 1985: 328ff.; Haspelmath 1987: 29ff.). In the cases where the markers of the passive and anticausative (at least partly) overlap, passives without an overtly expressed agent can be distinguished from anticausatives only by semantic criteria. This semantic opposition is characterized, for instance, by Comrie (1985: 326) as follows:

Passive and anticausative differ in that, even where the former has no agentive phrase, the existence of some person or thing bringing about the situation is implied, whereas the anticausative is consistent with the situation coming about spontaneously.

This general definition is also relevant for a description of the system of intransitive derivations in a number of Ancient Indo-European languages, such as Ancient Greek or (Vedic) Sanskrit. 
In what follows I will focus on the Vedic verbs with the suffix -ya-, particularly on the genesis of their accentuation. Generally, the -ya-presents with the accent on the suffix are passives (kriyáte 'is made', ucyáte 'is called', stūyáte 'is praised', hanyáte 'is killed'), whereas the -ya-presents with root accentuation behave as non-passive intransitives (cf. pádyate 'falls', búdhyate 'wakes', ríyate 'flows'). However, a few -ya-formations are generally regarded as exceptions to this regularity. The parade examples include mriyáte 'dies' (root $m r$ ) and its semantic counterpart jấyate 'is born' (root jan).

\section{Non-passive -ya-presents with suffix accentuation: the type mriyáte}

One of the most debated Vedic verbal formations relevant for a study of the accentual history of the -ya-presents is mriyáte 'dies'. While its semantic opponent, jấyate (on which see next Section), is regarded as a passive by meaning, non-passive by form, mriyáte is taken as a passive by form, but non-passive by meaning, being quoted in all Vedic and IndoEuropean grammars as a handbook example of the non-passive usage of a -ya-present with suffix accentuation. ${ }^{1}$ A few attempts to analyse this present as a passive proved unsuccessful. For instance, Negelein (1898: 38) treated it as the passive of the transitive $m \bar{r}\left(<^{*} m e l H^{-}\right)$ 'crush, destroy' ["Der Inder mag sich den Hergang des Todes sehr wohl als ein Zermalmtwerden (mr malmen) vorgestellt haben”], which is etymologically impossible. Hartmann in his book Das Passiv. Eine Studie zur Geistesgeschichte der Kelten, Italiker und Arier (Hartmann 1954: 186ff.) even assumed a particular passive conceptualisation of death in Ancient India. The fact that two verbs which belong to one and the same semantic domain, jấyate 'is born' and mriyáte 'dies', show such a striking dissimilarity in accentuation, which generally corresponds to the functional opposition "passive/non-passive", did not escape his attention. But his conclusions from this remarkable fact in the vein of Geistesgeschichte are untenable:

Trotz gewisser Übereinstimmungen im Gefühlswert beider Verba kann jedoch kein Zweifel darüber bestehen, daß das Ausmaß des ,passiven’ Einschlages jấyate geringer gewesen sein muß als bei mriyáte , da das Gefühl des Ausgeliefertseins an eine außerhalb des Subjektes liegende Macht bei einem Ausdruck für das Zurweltkommen einer Seele nicht so groß gewesen kann wie beim Sterben.

Needless to say that this explanation hardly deserves any serious discussion: mriyáte never functions as a passive (see e.g. Jamison 1983: 150, fn. 92), and, semantically, belongs with the root-accented '-ya-presents of change of state, together with its counterpart jấyate 'is born'. An explanation of the abnormal suffix accentuation can be given in phonological terms, and it holds also for a few other 'formal passives' ('pseudo-passives') made from the roots of the type $C r$, where the suffix ('passive') accentuation must be of secondary nature. This class also includes dhriyáte 'stays' and $\bar{a}$-driyáte 'heeds'. From the semantic and syntactic point of view and in spite of their suffix accentuation, the presents -driyá-te, dhriyá-te, mriyá-te (as well as ghriya-te and -sriya-te, which do not occur unambiguously accented) can be easily grouped with the nonpassive middle '-ya-presents of the three main classes, which include: ${ }^{2}$

${ }^{1}$ Cf. Delbrück 1874: 167f.; Whitney 1889: 277, §277; Macdonell 1910: 333, §444a.

2 The non-passive character of these three presents was probably the main reason which has caused the Indian grammarians to group these formations (together with the post-Vedic - priyate [with the preverb $\bar{a}$ ] 'be occupied, employed'; cf. DhP VI 109) with class VI presents; cf. Pān. 1.3.61. In Western scholarship this analysis was 
1) verbs denoting changes of state $^{3}$ (mostly of spontaneous and non-controllable character): jan i 'be born' - jấya-te RV+, pyā ‘fill, swell' - pyááya-te RV+, budh $(\alpha)^{4}$ ‘(a)wake’ búdhya-te $\mathrm{RV}+, l i \bar{l}(\alpha)$ 'dissolve' - líya-te RVKh.+;

2) verbs of motion and body posture: pad 'fall, move' - pádya-te RV+, ${ }^{1} y \bar{a}$ 'drive, speed' '́ya-te RV+, rī 'whirl, swirl' - ríya-te RV, VS1x, lì $(\beta)$ 'adhere' - -lìya-te Br.+;

3) verbs of mental activities, constructed with the accusative: $k \bar{a}$ 'long (for), yearn' káya-te $\mathrm{RV}^{1 \times}$, budh $(\beta)$ 'perceive' - búdhya-te $\mathrm{AV+}$, man 'think, respect' - mánya-te $\mathrm{RV+}$ $m r s ̦$ 'forget' $-m r s ̦ y a-t e ~ R V+$.

No doubt, the similar morphological marking of these presents reflects their semantic affinity within the Vedic verbal system. Note that for all these semantic types, middle voice marking is typical in the world languages (see Kemmer 1993; 1994: 182f. et passim). In spite of the small range of classes (1-3), their relevance within the Vedic verbal system is obvious. These types determine which meanings are productive (and, hence, "morphologically influential") in the class of middle -ya-presents, and which are not. For instance, the relevance of type (2) may account for the secondary and more recent usage of budhya-te, which originally (in the RV) could only be used in the intransitive usage $(\alpha)$, meaning '(a)wake'; after the RV, when the class I present bódha-ti 'perceive' disappears, búdhya-te takes over its function, thus being grouped together with such present formations as mánya-te 'think, respect' or mrşya-te 'forget'.

All verbs of the type mriyá-te perfectly fit the three semantic classes listed above. mriyá-te denotes a change of state (note, particularly, the parallelism with jáa $y a_{-t e}$, which will be discussed at length below, in Section 3); dhriyá-te (together with the hapaxes ghriya-te and -sriya-te) belongs with verbs of motion and body posture; -driyá-te refers to a mental activity. Moreover, even the secondary meaning of dhriyáte $(\beta)$ 'decide, determine', attested from Middle Vedic (Brāhmaṇas) onward, perfectly fits class (3), too. Thus, within the verbal system, all these Criyá- presents belong with the middle '-ya-presents, and even their later developments are determined by the semantic skeleton (1-3), as shown in Table 1 below: 6

Thus, the suffix ("passive") accentuation in the first three presents of the type mriyáte must be of secondary origin. All these formations are derived from $\mathrm{Cr}$ roots and, together with -yá-passives of the same structure (kriyáte 'is made', bhriyáte 'is carried' etc.), represent a specific development of $r$ before the present suffix -ya-. Most likely, the regular reflex of ${ }^{*} C_{o r}{ }_{0} i V$ was such that it disturbed the morphological transparency of the formation (for instance, ${ }^{* *}$ múryate). ${ }^{7}$ The only way to preserve the transparency of the form was to introduce the accent on the suffix: ${ }^{*} C_{o}$ - $-i a-\rightarrow$ Criyá- (i.e.: ${ }^{*} m r \dot{r}-i a-\rightarrow$ mriyá- etc.). Here the type kriyáte (where -ri- goes

usually regarded as mere misunderstanding (see e.g. J. Schmidt 1875: 244ff.; cf. also Benfey 1866a: 198f.). In fact, however, the segmentation mriy-á- is the only possible synchronic solution of the descriptive conflict between the "passive" form and the non-passive meaning of these presents: class VI is the only thematic present with the accent on the thematic vowel (cf. $k s ̦ i$ 'dwell' - kșiy-á-ti).

${ }^{3}$ See Levin 1993: 240ff., with bibl.

${ }^{4}$ Hereafter I use Greek characters $(\alpha, \beta)$ to refer to different meanings of polysemous -ya-presents.

${ }^{5}$ Cf. M. Leumann 1940: 232 [= K1.Schr., 323]; Gonda (1951: 92): "the two verbs [= mriyáte and jáyate. - L. K.] 'formed a pair' and influenced each other".

${ }^{6}$ This must also hold true for the presents ghriya-te 'drip' and -sriya-te 'stretch', which do not occur accented, but, by virtue of their phonological structure can only bear accent on the suffix: *ghriyá-te, *-sriyá-te.

${ }^{7}$ Cf. dí $r v \bar{a}-<*$ dŕueH- (Lubotsky 1997: 148, with fn. 29). Note that the -ya-presents (including -yá-passives) derived from roots ending in long sonants (such as púrya- 'become full' < $\left.{ }^{*} p r H-i a-\right)$ are not discussed in this paper. On the Avestan reflexes of *Cŕi- (Crii-, Cirii-), see Beekes 1999: 64. 
Table 1. The main semantic classes of the middle '-ya-presents and the corresponding presents of the type Criyá-te

\begin{tabular}{|c|c|c|c|}
\hline \multirow{2}{*}{-yá-presents } & \multicolumn{3}{|c|}{$\begin{array}{l}\text { passives } \\
\text { (yujyáte, dīyáte, hanyáte, kriyáte, ...) }\end{array}$} \\
\hline & mriyáte & $\begin{array}{l}\text { dhriyáte }(\alpha) \text {, -sriyate, } \\
\text { ghriyate }\end{array}$ & -driyáte, dhriyáte $(\beta)$ \\
\hline \multirow{2}{*}{$\begin{array}{l}\text { middle } \\
\text { '-ya-presents }\end{array}$} & $\begin{array}{l}\text { change of state (jấyate, } \\
\text { búdhyate }(\alpha), \ldots)\end{array}$ & $\begin{array}{l}\text { motion and body pos- } \\
\text { ture (pádyate, rínate, ...) }\end{array}$ & $\begin{array}{l}\text { mental activities } \\
\text { (mányate, búdhyate }(\beta), \ldots)\end{array}$ \\
\hline & (1) & (2) & (3) \\
\hline
\end{tabular}

back to the accentless - $r$ - before - $i$-) may have served as a model. Due to this accent rule, presents of the type mriyáte, which originally belonged with middle '-ya-presents, formally fell together with -yá-passives. ${ }^{8}$

\section{3. jấyate 'is born' - anticausative or former passive?}

According to the opinion widely spread in earlier Indo-European and Indo-Iranian studies, jấyate (as well as its Old-Iranian cognate, Avestan zaiieiti) is the original passive, with the secondary accent shift in Vedic. Whitney in his seminal Sanskrit grammar (1889: 273, §761b) called it 'altered passive'; likewise, Macdonell in his Vedic grammar (1910: 333, §444a) claims that the original passive has been "transferred to the radically accented ya- class": *jāyáte- $\rightarrow$ jấyate. Similar statements can also be found in later studies. ${ }^{9}$ There is no sufficient evidence for such a hypothesis, however. Although a passive interpretation ('is born by smb.') is possible per se, it cannot be supported by the syntactic features of jan. Witness the following examples from the Rgveda and Śatapatha-Brāhmana:

(1) RV 6.7.3a

$\begin{array}{lllll}\text { tvád } & \text { vípro } & j \bar{a}-y a-t e & \text { vājy } & \text { àgne } \\ \text { you:ABL } & \text { poet:NOM.SG } & \text { bear-YA-3SG.MED } & \text { prize-winner:NOM.SG } & \text { fire:VOC.SG }\end{array}$

'From you, o fire, is born the poet, the prize-winner.'

${ }^{8}$ For a detailed discussion of this morphological type, see Kulikov 1997. On the secondary accent shift in mriyáte, see also Szemerényi 1964: 184, fn. 1. It is worth mentioning that a number of Indo-Europeanists and Sanskritists, without explicitly formulating the conditions of this process, have suggested the secondary character of the suffix accentuation in this present type; cf., for instance, the remark by Kellens (1984: 121, note (8)): "Le sens ne permet pas de considérer mriyá- comme le passif de mára-: l'accent suffixal paraît donc secondaire”. On the partial overlapping of the -ya-stems built on some $C_{o}$ and $C R \breve{\bar{l}}$ roots (vacillation CRìya-/CRiya-), see Kulikov 2005.

9 jấyate is qualified as an original passive, e.g. in Mayrhofer's grammar (1965: 93, 93), albeit not consistently; see Hauschild 1965: 216; cf. also Hartmann 1954: 186f.; Etter 1985: 215, fn. 290; 245; Kellens 1984: 126ff., note (15); Werba 1997: 288 (“intr. Pr. [=Pass.]”). 
(2) ŚB 5.3.5.17

agnér vái dhūmó jāa-ya-te,

fire:ABL.SG verily smoke:NOM.SG bear-YA-3SG.MED

dhūmád abhrám viŕștị

smoke:ABL.SG cloud:NOM.SG cloud:ABL.SG rain:NOM.SG

'Verily, from the fire the smoke arises, from the smoke the cloud, from the cloud the rain.'

The most important piece of evidence for a non-passive analysis of jánate is the lack of constructions with the instrumental of the agent (= the one who begets), which would be typical for a true passive construction (see Hock 1985-86: 90, fn. 5), as in (1a):

\section{(1a) *toáyā vípro jā-ya-te \\ you:INS poet:NOM.SG bear-YA-3SG.MED \\ 'The poet is born by you (o fire).'}

Besides, there are no good phonological reasons which could explain the supposed accent shift: *jāyáte- $\rightarrow$ jấyate. Most likely, jấyate belonged with anticausatives, not with passives, from the very beginning, meaning 'come into being, arise'. Then, how the widely spread passive analysis of jấyate can be explained? I presume it may have emerged under the influence of the passive morphology of its translations in European languages, such as Engl. is born, Germ. ist geboren, Fr. est né. Note, incidentally, that the Russian translation of this Vedic verb seems to be free of such dangerous side effects: Rus. рождаться 'be born' is a nonpassive intransitive (anticausative), which cannot be employed in passive constructions of the type ' $X$ is born by smb.'

\section{4. -ya-presents with fluctuating accentuation}

There are some twenty Vedic -ya-presents attested with boot root and suffix accentuation, cf. múcya-te / mucyá-te 'be released, become free', kșínya-te / kṣīyá-te 'perish, disappear', etc. (hereafter referred to as “'-yá-presents”). According to standard Vedic grammars, this fluctuation is not random only in case of pacyáte 'is cooked' vs. pácyate 'ripens' (as in RV 1.135.8 pácyate yávah 'the barley ripens'). In what follows, I will concentrate on synchronic features and diachronic origins of this verbal class.

\subsection{Historical distribution of accentuation in Vedic texts}

As noticed above, the accent fluctuation of the type múcya-te / mucyá-te does not follow any semantic regularity (except for pácyá-te). The few attempts at explaining the place of the stress in terms of the passive/non-passive distinction (cf. Gonda 1951: 98f.), parallel to the opposition pacyáte 'is cooked' vs. pácyate 'ripens' clearly faltered. We find forms with different accentuation in nearly identical contexts and even parallel passages which differ only in accentuation; cf. RV 10.152.1 jínate = AV 1.20.4 jīyáte. The accentuation of the '-yá-presents is not random, however, as Table 2 below shows (the numbers in superscript indicate the number of accented occurrences): 
Table 2. Accentuation of the -ya-presents with fluctuating accentuation in Vedic texts

\begin{tabular}{|c|c|c|}
\hline '-yá-presents & $\begin{array}{c}\text { ' }-y a- \\
\text { attestations with root accentuation }\end{array}$ & $\begin{array}{c}-y a ́- \\
\text { attestations with suffix accentuation }\end{array}$ \\
\hline
\end{tabular}

Verbs of destruction and destructuring ('entropy increase')

\begin{tabular}{|c|c|c|}
\hline ŕdhyáte 'is successful'; + ví 'loses' & $\mathrm{TS}^{1}, \mathrm{SB}^{1}$ & DS1, MS1 ${ }^{1}$ ŚB 1 , ŚBK¹ \\
\hline kșíyáte 'perishes' & $\mathrm{RV}^{1}, \mathrm{TS}^{2}, \mathrm{~B}^{2}(B \overline{\mathrm{A}} \cup), \mathrm{T} \overline{\mathrm{A}}$ (act. $)^{1}$ & $\mathrm{AV}^{1}, \mathrm{SB}^{6}, \mathrm{~TB}^{1}$ \\
\hline chídyáte 'breaks, is cut off' & $\mathrm{TS}^{1}, \mathrm{SBR}^{1}$ & $\mathrm{MS}^{2}, \mathrm{SB}^{3}$ \\
\hline jíyáte 'suffers loss' & $\mathrm{RV}^{1}, \mathrm{RV}-\mathrm{SV}^{1}{ }^{1}, \mathrm{TS}{ }^{1}, \mathrm{SB}^{1}(\mathbb{A} \mathrm{U} \cup)$ & $\mathrm{AV}^{3}, \mathrm{MS}^{2}$ \\
\hline díryáte 'cracks, is split' & $\mathrm{TS}^{2},+\mathbb{M S} 2$ & Ś $\mathrm{SB}^{4}$ \\
\hline púryáte 'becomes full' & $\mathrm{RV}^{1}, \mathrm{MS}_{1}, \mathrm{~TB}^{\mathrm{m} 2}, \mathrm{~T} \overline{\mathrm{A}}$ (act. $)^{2}$ & $\mathrm{MS}^{1}, \mathrm{SB}^{12}, \mathrm{BB}^{1}$ \\
\hline bhídyáte 'breaks' & RVKh. ${ }^{1}, \mathrm{TS}^{2}$ & $\mathrm{MS}^{2}, \mathrm{SB}^{10}, \mathrm{Ś}^{\mathrm{B}} \mathrm{K}^{1}, \mathrm{Kaṭh} \overline{\mathrm{A}}^{1}$ \\
\hline míyáte 'is damaged, perishes' & $\mathrm{RV}^{2}, \mathrm{TS}^{7}, \mathrm{~TB}^{3}, \mathrm{TA}^{2}$ & $\mathrm{MS}^{4}$, ŚB $^{1}$ \\
\hline múcyáte 'becomes free’ & $\mathrm{RV}^{1}, \mathrm{RVKh} .{ }^{1}, \mathrm{AV} 1, \mathrm{TS}^{2}$ & $\mathrm{AV}^{3}, \mathrm{SB}^{9}, \mathrm{Ś}^{\mathrm{B}} \mathrm{K}^{3}$ \\
\hline $\begin{array}{l}\text { rícyáte 'is emptied'; } \\
\text { + áti, prá 'surpasses; is left over' }\end{array}$ & $\mathrm{TS}^{7}, \mathrm{~TB}^{9},\left(+\mathrm{TA}^{1}(?)\right)$ & $\mathrm{MS}^{6}, \mathrm{MS}^{-K S^{1}}, \mathrm{Ś}^{12}, \mathrm{Ś}^{\mathrm{B}}{ }^{5}$ \\
\hline lúpyáte 'is damaged, torn' & $\mathrm{TS}^{1}$ & $\mathrm{AV}^{1}, \mathbb{T} \mathbb{B} 1$ \\
\hline śiṣyáte 'is left over' & $+{ }^{+} \mathbb{N}_{1}, \mathrm{TS}^{2}, \mathrm{~TB}^{3}$ & $\mathrm{MS}^{1}, \mathrm{SB}^{10}, \mathrm{Ś}^{4} \mathrm{~K}^{4}$ \\
\hline śíyáte 'falls (off)' & $\mathrm{TS}^{-\mathrm{TB}^{1}}, \mathrm{MS}^{2}, S \mathrm{~B}^{1}, \mathrm{~TB}^{1}$ & $\mathrm{SB}^{1}, \mathbb{1 B} 3$ \\
\hline śíryáte ‘breaks, collapses’ & $S_{B}^{1}(B \bar{A} U)$ & $\mathrm{MS}^{1}, \mathrm{KS}^{1}$ \\
\hline híyáte 'is left, abandoned' & $\mathrm{TS}^{4}, \mathrm{SB}^{1}$ & $\mathrm{MS}^{2}, \mathrm{SB}^{2}$ \\
\hline
\end{tabular}

\section{Verbs of heating}

\begin{tabular}{|c|c|c|}
\hline tápyáte 'heats; suffers' & VS (act. $\left.{ }^{1}, \operatorname{med} .{ }^{1}\right), \mathrm{TS}^{\mathrm{m} 1}, \mathrm{NS} \mathrm{m} 1, \mathrm{SB}^{3}, \mathrm{~TB}^{2}$ & $\mathrm{AV}^{6}, \pi \mathrm{m} 1, \mathrm{SB}^{4}$ \\
\hline dáhyáte 'burns' & $\mathrm{RVKh}^{2}$ & TS1, MS-KS1, ŚB 4 \\
\hline $\begin{array}{l}\text { pácyáte 'is cooked; ripens, } \\
\text { is digested' }\end{array}$ & 'ripen': RV11, +RVKh. ${ }^{1}$, ŚB $^{1}, \mathrm{~TB}^{1}$ & 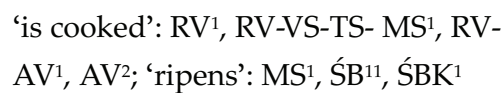 \\
\hline
\end{tabular}

The simple regularity, which immediately follows from the above table can be formulated as follows:

- in the Rg-Veda (together with the RV-Khilāni) and in the texts of the Taittirìya school (Taittirīya-Saṃhitā, Taittirīya-Brāhmaṇa and, probably, Taittirīya-Āranyaka), '-yá-presents show root accentuation;

- in the Atharva-Veda, Maitrāyan̄ī Saṃitā, Śatapatha-Brāhmaṇa and, most likely, in the texts of the Kāṭhaka school, '-yá-presents show suffix accentuation. 
While evidence provided by the RV, AV, MS, ŚB and the accentuated texts of the Taittirīya school is quite sufficient to make decisive conclusions on the accentual patterning of the '-yá-presents in these texts, the case of the Kāțaka (KS) is less clear. The overwhelming majority of the '-yá-presents occur in the unaccentuated parts of the text in ed. Schroeder; evidence consists of only three attestations (dahyámānā KS 10.5:130.6-7, ati-ricyáte KS 14.10:209.6, api-śìryáte KS 35.16:62.2). Yet, in spite of the scarcity of attestations, the three accented occurrences (to which one form in the Kața-Āranyaka may be added) as well as the close affinity of the language of the Kățhaka and Maitrāyaṇi schools lead to the assumption that the corresponding dialects belong together as far as the accentual patterning of the '-yá-presents is concerned.

Still more problematic is the position of the dialect of the Vājasaneyins. The only '-yá-present which occurs accented in the VS is tápyá-te (tápyamānāya VS 39.12). ${ }^{10}$

The aforementioned distinction holds foremost for the larger semantic class of '-yá-presents, which includes verbs referring to (spontaneous) destruction and some related processes (for a detailed semantic analysis of the '-yá-presents see Section 4.4 below). More intricate is the case of the second, smaller, semantic class, which includes verbs of heating. In the RV, the place of the accent in pácyátte depends on its meaning ('be cooked/ripen'). The ŚB and MS have generalized the suffix accentuation (except for one root-accented occurrence in the ŚB), as in the case of the verbs of destruction; the root accentuation of the only accented occurrence in the TB matches both its semantics ('ripen') and the rule of accent placement in the Taittirīya and therefore does not prove anything. Likewise, dáhyátte (unattested in the RV) essentially follows the model of the verbs of destruction, except for one occurrence in the TS. Most complicated is the situation with tápyá-te. In the AV, all the accented forms bear accent on the suffix, whilst in the TB the accent is on the root, which meets our rule. The accent placement in the Saṃhitās of the Yajurveda (TS, MS) seems to be random; note, however, that both occurrences which do not meet the rule (TSm 3.2.8.2 anu-tapyámāna- $\approx$ anu-tápyamāna$\mathrm{MS}^{\mathrm{m}}$ 2.3.8:37.1) appear in a mantra - that is, in the older language (which may represent an earlier situation as compared to what we observe at the later stage of the development of the same Vedic dialects, in Vedic prose). All the three root-accented occurrences attested in the ŚB are imperatives (met with in one passage), while the suffix accentuation is attested in indicative forms.

From the rule formulated above it immediately follows that (i) the suffix accentuation of the '-yá-presents in the AV, MS and ŚB does not suggest their passive value or any particular semantic difference from the corresponding forms with the root accentuation attested in the RV(Kh.) and Taittirīya - contra Gonda 1951; (ii) there are no good reasons to emend the suffix accentuation in these texts on the basis of non-passive semantics (cf. Insler 1987: 62f. on AV kșìnate). The accent fluctuation does not depend on the semantics of the -ya-presents in question, but represents a difference between Vedic schools/dialects.

\subsection{Exceptions to the general rule}

Exceptions to our rule are relatively few among the 'entropy increase' verbs (shown with the outline letters in Table 2 above); for convenience, they are summarized in Table 3 below:

${ }^{10}$ The nonce formation tápyate (dat.sg. act.prt.), attested in the same passage, is a secondary replacement of the class I active participle (tápate) and thus cannot serve as evidence for the accentual patterning of tápyá-te in this text; moreover, it may even have triggered the root accentuation of the adjacent tápyamānāya. 
Table 3. -ya-presents with fluctuating accentuation: exceptions to the general accentual pattern

\begin{tabular}{l|c|c}
\hline '-yá-presents & $\begin{array}{c}\text { '-ya- } \\
\text { root accentuation instead of the } \\
\text { expected suffix accentuation }\end{array}$ & $\begin{array}{c}-y a^{\prime}- \\
\text { suffix accentuation instead of the } \\
\text { expected root accentuation }\end{array}$ \\
\hline
\end{tabular}

Verbs of destruction and destructuring ('entropy increase')

\begin{tabular}{|c|c|c|}
\hline $\begin{array}{l}\text { ŕdhyá-te 'is successful'; } \\
+ \text { ví 'loses' }\end{array}$ & vy-ŕódhyai ŚB 2.1.2.4 & rdhyáte TS 1.5.2.2 \\
\hline kșíyá-te 'perishes' & $\begin{array}{l}\text { kșíyate ŚB 14.4.2.28, } \\
\text { kșíyeta ŚB 14.4.3.7 }\end{array}$ & apa-kșīyáte ТВ 1.5.10.5 \\
\hline chídyá-te 'breaks, is cut off' & vy-ava-chídyai ŚBK 2.8.3.18 & \\
\hline jíyá-te 'suffers loss' & júyate ŚB 14.4.3.23 & \\
\hline dìryá-te 'cracks, is split' & +díryeta MS 2.1.8²× $: 9.14,15$ & \\
\hline púryá-te 'becomes full' & prati-púryeta MS 3.2.2:17.11 & ā-pūryáte TB 1.5.10.5 \\
\hline múcyá-te 'breaks' & múcyātai AV 8.8.6 & \\
\hline lúpyá-te 'is damaged, torn' & & lupyáte $\mathrm{TB}^{\mathrm{m}}$ 2.8.8.2 \\
\hline śísyáte 'is left over' & ${ }^{+}$uc-chiṣyātai AV 2.31.3 & \\
\hline śítyá-te 'falls (off)' & 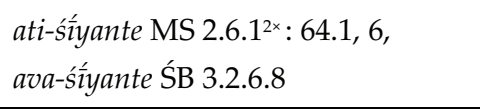 & ava-śìyánte $\mathrm{TB}^{\mathrm{m}}$ 3.12.7.2-3× \\
\hline śíryá-te 'breaks, collapses' & śíryate ŚB 14.6.9.28 etc. & \\
\hline híyá-te 'is left, abandoned' & híyate ŚB 3.6.2.14 3.6.2.15 & \\
\hline \multicolumn{3}{|c|}{ Verbs of heating } \\
\hline tápyá-te 'heats; suffers' & $\begin{array}{l}\text { anu-tápyamānāh MSm 2.3.8:37.1, } \\
\text { tápyadhvam, tápyasva² ŚB 6.1.3.2-4 }\end{array}$ & anu-tapyámānā TSm 3.2.8.2 \\
\hline
\end{tabular}

Most exceptions fall into one of the following types:

(1) eleven non-indicative forms with suffix accentuation instead of root accentuation:

- subjunctives: vy-ŕdhyai ŚB 2.1.2.4, 'vy-ava-chídyai ŚBK 2.8.3.18, múcyātai AV 8.8.6, ${ }^{+} u c-$ chísyātai AV 2.31.3;

- optatives: kșíneta ŚB 14.4.3.7, +dî́ryeta MS 2.1.82× : 9.14, 15, prati-púryeta MS 3.2.2:17.11;

- imperatives: tápyadhvam, tápyasva² ŚB 6.1.3.2-4.

The tendency to bear the accent on the root in the non-indicative forms of '-yá-presents in the AV, MS and ŚB was by no means a strict rule, however: we find subjunctives and optatives with the accent on the suffix as well, cf. jìyéta MS 1.6.10:103:2, dìryéta ŚB 4.5.10.72x, bhidyéyātām ŚBK 4.9.4.15, etc. On the assumption that in the corresponding Vedic dialects the accent was retracted from the suffix to the root, the root-accented forms listed above can be regarded as preserving the original accentuation (see Section 5.2 below). 


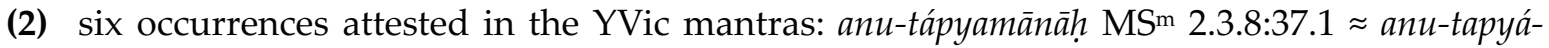
mānā $\mathrm{TS}^{\mathrm{m}}$ 3.2.8.2, lupyáte $\mathrm{TB}^{\mathrm{m}}$ 2.8.8.2,11 ava-śìyánte $\mathrm{TB}^{\mathrm{m}}$ 3.12.7.2-33. One may assume that the accent shift in some YVic dialects was completed by the beginning of the Brāhmana period, while the mantras attest the transitional period and vacillation in accent placement.

(3) four exceptions in the last chapters of book 14 of the ŚB [= BĀU] (kșínate ŚB 14.4.2.28 [= BĀUM 1.4.28], kșíyeta ŚB 14.4.3.7 [= BĀUM 1.5.7], j2 jíyate ŚB 14.4.3.23 [= BĀUM 1.5.23 = BĀUK 1.5.15], śíryate ŚB 14.6.9.28 [= BĀUM 3.9.28] = ŚB 14.6.11.16 [= BĀUM 4.2.6] = ŚB 14.7.2.27 [= BĀUM 4.4.27]) must be due to the late character of the text, which not infrequently gives erroneous accents; cf. ̄yámāna- ŚBv 14.7.1.14 [= BĀUMv 4.3.14], manyấsai ŚB 14.6.9.26 [= BĀUM 3.9.26], manyáte ŚB 14.9.2.7 [thus mss.; ed. Weber mányate], sájyate ŚB 14.6.9.28 [v.l. apud ed. Weber].

(4) for śiya-te, there may have existed additional semantic rules which determined accent placement in some usages, see Kulikov 2011, s.v. for details.

(5) only four exceptions seem unmotivated: radhyáte TS 1.5.2.2, híyate ŚB 3.6.2.14 3 3.6.2.15, apakṣìyáte and à-pūryáte in TB 1.5.10.5.

\subsection{Instances of semantically motivated accent shift}

To sum up, for the majority of '-yá-presents the accent fluctuation does not involve any semantic or syntactic features. Thus, the standard explanation of the accent shift in -yá-passives as motivated by the non-passive (reflexive or anticausative) syntax ${ }^{13}$ finds no or little support in the linguistic facts. The only clear instance of an opposition correlated with the place of accent is pácyá-te, employed in the sense 'be cooked' or 'ripen', depending on its accentuation (on the suffix vs. on the root; for references, see Kulikov 2001, 2011, s.v.). This correlation seems to hold true only for the language of the RV, however (where, incidentally, the root accentuation is attested only once, at RV 1.135.8, against three instances of suffix accentuation). Note, furthermore, that the semantic opposition 'be cooked' 'ripen' does not amount to the passive/non-passive distinction, but suggests an idiomatic change (lexicalization).

Another instance of semantic motivation may be dáhyá-te, which occurs with the root accentuation in the RVKh. ('burn [by itself]') and with the suffix accentuation in the Vedic prose (TS, MS-KS, ŚBK) ('be burned [by fire]'), but this semantic distinction is too subtle and evidence rather scant. Besides, four of the five occurrences follow the accentual patterning attested for verbs of destruction, the only exception being TS 5.5.2.3 dahyámānā.

\subsection{Semantics of the '-yá-presents}

The middle -ya-presents with fluctuating accentuation represent, in a sense, a 'bridge' between -yá-passives and non-passive middle '-ya-presents. This small class reveals a remarkable semantic and structural similarity. ${ }^{14}$

11 The suffix accentuation of lupyáte could also be triggered by the adjacent -yá-passives appearing in the same passage.

12 This occurrence belongs to the first group of exceptions as well.

${ }^{13}$ Cf. Pānini's sūtra 6.1.195 acah kartr yaki 'before [the passive suffix] -ya- [in verbs with the roots ending] in a vowel $(a C$-) [the root optionally bears the accent if the verb is employed] in the reflexive [usage]'.

${ }^{14}$ For a discussion of the semantic features of the '-yá -presents, see Kulikov 1998a, 1998b. 
The main subclass of the '-yá-presents can be defined in semantic terms as follows. A good deal of these verbs denote processes of spontaneous destruction: breaking, bursting (in the Brāhmanas often said of sacrificial vessels), splitting, as well as destruction in general ('disappear', 'perish', etc.), cf. kșíyá-te 'perish, disappear'; chídyá-te 'break, cut off'; dî́ryá-te 'crack, split, burst'; bhidya-te 'break, split'; mî́yá-te 'damage, perish'; lúpyá-te 'damage, tear'; śíryá-te 'break, collapse'. The definition of another subclass (múcyá-te, etc.) poses some problems. Intuitively, the meanings of mucyate 'becomes free', śìyate 'falls', śișyate 'is left over', etc. are rather close to the semantic domain of destruction, but their common denominator is difficult to capture. Yet, one may argue that they all denote a process when an element ceases to be incorporated into a system or structure - for instance, some part(s) of an object break off and fall down - which, ultimately, results in the destruction of a system. Specifically, mucyate 'becomes free, is released' can be determined as 'ceases to be bound, included into a bound system'; śișyate 'is left over' and hìyate 'is abandoned, is left over' $\approx$ 'remains outside a structure'; śìnate 'falls (out)' $\approx$ 'ceases to be included into a structure through falling out of it'. At first glance, rdhyate 'is successful, fulfilled, goes well' does not belong to this semantic type; but its meaning changes to the opposite in compounds with the preverb ví: 'is deprived of [a property], loses', i.e. 'ceases to be connected with some (structural) elements'; cf. jiyate 'suffers loss', which is very close. ricyate belongs here both when employed as a simplex ('is emptied' $\approx$ 'is deprived of its content') and with the preverbs áti, prá ('surpasses, is redundant' $\approx$ 'goes beyond the scope of a structure'; 'is left over'). For this subgroup I propose the tentative label 'verbs of destructuring'.

In my view, we are able to determine an even more general semantic feature which encompasses the meanings of both 'destruction' and 'destructuring'. All these verbs denote spontaneous "fatal" processes which result in destroying some natural or artificial system or organism, and, to put it in general terms, in the entropy increase. ${ }^{15}$

In this semantic perspective, instructive is the present śíyá-te, whose semantics does not amount to falling down. In one of its usages, śítyá-te refers to a particular kind of falling, which accompanies natural decay, growing old: falling out of hairs, teeth, etc., i.e. typical instances of entropy increase. Cf. also JB 1.1 bhasmāvaśìyate 'some borings fall down [from the piece of kindling wood being churned]', on which Bodewitz (1973: 21f., note 4) comments that "bhasma refers to wooden dust falling of the wood sticks during the churning, a product of erosion [emphasis is mine. - L. K.]" - again, a typical instance of entropy increase.

The verb $p \bar{r}$ ' fill' cannot be included into the class of 'entropy increase' verbs in any of its usages. Yet, in the compound with the preverb $\bar{a}$ it functions as the counterpart of an 'entropy increase' verb, $k s \underline{\breve{\imath}}$ (with the preverb ápa): $\bar{a}-p \bar{r}$ ' wax' and ápa-kṣ̂̆ 'wane' denote opposite changes of the half-moon.

The semantic affinity of the 'entropy increase' verbs is also supported by the fact that they often co-occur in texts. To mention a few passages: TB 1.5.10.5, ŚB 1.7.2.22, 2.1.3.1, 2.4.4.18, 19, 8.4.1.10, 10.4.2.17 (co-occurrence of ápa-kṣŭ and $\bar{a}-p \bar{r}$ ); PB 6.7 .15 (ava-chid, vy-rdh, jī); TS 7.2.1.4, MS 1.6.10, 1.8.7, AV 10.1.32 (muc, hā); ŚB 3.1.1.3 ((abhy)áti-ric, śiṣ), TS 3.2.9.5, AB 6.2.6 (lup, hā). ${ }^{16}$

The second, smaller, semantic class of '-yá-presents includes three verbs of heating: tápyá-te 'heat, suffer', dáhyá-te 'burn', pácyá-te 'cook; ripen'.

${ }^{15}$ For a detailed discussion of this semantic feature, see Kulikov 1998a.

${ }^{16}$ Cf. Gonda 1959: 204. 


\subsection{Paradigmatic features}

The most remarkable paradigmatic feature shared by the '-yá-presents of entropy increase is their opposition to transitive-causative presents with nasal affixes (cf. kṣ̂́yáte - kșinấti, kṣinóti, chídyáte - chinátti, lúpyáte - lumpáti, etc.). By contrast, the three '-yá-presents of heating are opposed to class I presents (tápyá-te - tápa-ti, dáhyá-te - dáha-ti, pácyá-te - páca-ti); for details, see Kulikov 2011, chapter C.III.2.

It seems that the paradigmatic similarity of the '-yá-presents could be an important feature of this verbal class, which supported their semantic affinity and, in some cases, could even trigger the rise of secondary transitive presents with nasal suffixes for some-ya-presents of this class; cf. such formations as śináști, śị̣ṣati.

\subsection{Phonological similarity}

Some types of phonological structures are particularly common among the '-yá-presents of entropy increase, while some others are unattested. Specifically, five stems (one third) show the structure Ciya-, four stems belong to the type CiCya-, three stems show the structure $\mathrm{C} \bar{\imath} / \bar{u} r y a-$. By contrast, all the three verbs of heating are derived from $\mathrm{CaC}$ roots, uncommon among verbs of 'entropy increase'. It is of course impossible to posit a strict correlation between phonological structures and semantic classes; however, the phonological similarity could additionally support the structural affinity of the verbs in question ${ }^{17}$ and cause accent shift in some -ya-presents of similar structures, even in spite of different semantics, in particular, in -vínante 'are impregnated' TS 6.1.7.1 ( Vvyā/vī), ìyámāna- 'speeding, driving' ( ل $y \bar{a}) \mathrm{MS}^{\mathrm{m}}$ 2.6.11:70.12, v.1. [three mss.], ŚBv 14.7.1.14 = BĀUMv 4.3.14); cf. esp. the parallelism $v y \bar{a} / v \bar{\imath}, y \bar{a} / \bar{\imath} \sim$ $j y \bar{a} / j \bar{\imath}$.

\subsection{Accent fluctuation of the type múcya-te / mucyá-te in a diachronic perspective}

The features shared by the '-yá-presents (semantics, non-passive syntax, opposition to transitive nasal presents, partial phonological similarity) belong to different layers of the language structure and are essentially independent of each other. This implies that the similarity of '-yá-presents cannot be mere coincidence, and they form a morphologically relevant verbal class, rather than a random group. Their semantics (entropy increase, heating) seems to be the main parameter organizing these verbs to a structural class and, eventually, determining their properties. For instance, this feature could trigger the emergence of the nasal presents śináști, śimșati (Br. +), built as transitive-causative counterparts of śișyá-te.

The 'entropy increase' semantics could also influence the accentual behaviour of a -ya-present even in the cases where it was registered only with some preverbs; cf. ŕdhyá-te 'be successful', which changes its meaning to the opposite ('be deprived, lose') in compounds with vi, and therefore follows the accentual pattern of the verbs of entropy increase. The same explanation probably holds true for the suffix accentuation of the non-passive vi-lipyáte (MS) 'comes unstuck [and falls off]' ( simplex lipya-te 'stick, smear').

${ }_{17}$ Recall the old theory of 'rime-words' and 'rime-ideas' (Reimwortbildungen) (Bloomfield 1895; Wood 1907/ 1908; Güntert 1914: 30ff. [on chid/bhid]; 65f. [on $k s \underline{\imath} / m \bar{\imath}]$ ). Note, incidentally, that the first of Wood's lists of rimewords (op.cit., 142f.), labelled 'dwindle' group, includes all the five aforementioned Cíyá- presents of the 'entropy increase’: kṣìyate, [jīyate] (Wood gives only the nasal present jináti), śìyate, mìyate, hìyate (though Wood does not mention accent fluctuation). 
Furthermore, the parallelism between $\bar{a}-p \bar{r}$ ' wax' and ápa-kș̆ 'wane' (the latter of which belongs to the 'entropy increase' type) has probably triggered changes in accent patterning of -púryá-te, in spite of the fact that this present does not show any meaning related to entropy increase.

On the other hand, some middle -ya-presents with the root accentuation were not grouped with the '-yá-presents (and hence did not change their accentuation) if their semantic affinity with the entropy increase class was not supported by other features. Thus, for instance, pádya-te 'fall', albeit similar to śíyá-te in meaning, does not show other features of the -ya-presents referring to 'entropy increase' (note, in particular, the root structure $\mathrm{CaC}$ and the lack of a transitive-causative counterpart with the nasal affix) and does not change to padyá-te in the dialects of the AV, MS and ŚB. ${ }^{18}$

The "intermediate" position of '-yá-presents between -yá-passives and non-passive middle '-ya-presents probably results from their peculiar semantics. Judging from their non-passive meanings and syntax (see above) as well as from their root accentuation in the Rgveda, originally these formations probably belonged with the class IV presents. Later on, in some contexts they could be re-interpreted as passives (in accordance with the scenario: 'breaks' $\rightarrow$ 'is broken [by smb.]'; 'becomes free' $\rightarrow$ 'is released', or the like) and, due to the increasing productivity of the -yá-passives, undergo accent shift in several Vedic dialects - in particular, in the dialects of the AV, Maitrāyaṇī-Kāthaka and ŚB. ${ }^{19}$

The great number of exceptions in the Yajurvedic mantras and the root accentuation of tápyamāna- in the Vājasaneyi-Saṃhitā as against the prevalent suffix accentuation in the Śatapatha-Brāhmana, which belongs to the same Vedic school (White Yajurveda), may point to the fact that the accent shift from the root to the suffix in the corresponding Yajurvedic dialects was only completed by the period of Vedic prose (Brāhmanas properly speaking).

\section{Concluding diachronic remarks on the accentual history of Vedic -ya-presents}

\subsection{The original accentuation of (middle) $-y a$-presents}

It is commonplace in Vedic studies to assume that all -ya-presents, irrespectively of accentuation and diathesis (i.e. both -yá-passives and class IV presents), go back to one source, ${ }^{20}$ and the correlation between accentuation and the passive/non-passive distinction is

${ }^{18}$ Not counting three occurrences with suffix accentuation in the late ŚB (books 11 and 14).

${ }^{19}$ Our knowledge of the Vedic dialectology is still rather poor (for a systematic treatment of the issue, see Witzel 1989), and we are thus far unable to draw any decisive conclusions on the localisation of the dialects in which this accent shift was operative. Nevertheless, relying upon Witzel's preliminary outline, one might tentatively assume that one of the centres of this process was the Kuru region (KS, early ŚB), whereas the dialect(s) of the Pañcala (where the TS can be tentatively located) were more conservative and have preserved root accentuation.

${ }^{20}$ I will not discuss here at length the highly controversial issue of the origin of the present suffix $-y a-$. Suffice it to mention that the morpheme -ya- must be historically identical in the middle class IV presents (with root accentuation) and -yá-passives, while some of the active -ya-presents may go back to a different (denominative?) source. For a survey of possible sources of the present suffix -ya- (resp. PIE *-ie/o-), see, in particular, Lubotsky 1985 (who demonstrates that the PIE source of Ved. śuṣ, i.e. ${ }^{*} H_{2} s u s$, must be an adjective, not a verbal root); Barton 1986: 143, fn. 27 ("many of the *ie/ ${ }_{0}$-intransitives are doubtless denominal in origin"); Rasmussen 1993: 480ff.; and Kortlandt's (1981: 127f.), who advocates the genetic relationship between Vedic - $i$-aorists, -áya-causatives and -yá-passives: the former may go back to "a deverbative noun of the type *kwori [> Ved. (á)kāri. - L. K.], which could 
an Indo-Aryan innovation. See, for instance, F. M. Müller 1864: 582; Delbrück 1874: 168; J. Schmidt 1875: 256f.; Hillebrandt 1880: 342f. [= K1.Schr., 606f.]; Speijer 1896: 49, §168; Brug-

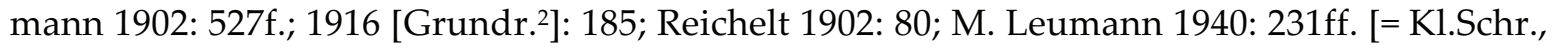
321ff.]; Gonda 1951: $7^{21}$ et passim; 1971: 90f.; Thumb/Hauschild 1959: 333ff.; Strunk 1967: 78. This assumption, based, above all, on the intransitivity of the majority of -ya-presents, immediately raises the question on the original place of accent: did they bear accent on the suffix or on the root? Evidence is controversial: the zero grade of the root may betray the original suffix accentuation, while the increasing productivity of -yá-passives and the archaic non-productive character of many class IV presents rather point to the root accentuation. Most scholars considered the root accentuation in the class IV presents secondary as against the suffix accentuation in -yá-passives; see already Benfey 1865: 1783 [= K1.Schr. II, 141]; 1866: 196; Saussure 1877; Froehde 1881: 172; Diels 1913: 4. ${ }^{22}$ Very plausible is Kuryłowicz’s (1952: 114f.) assumption that accent retraction to the root in class IV presents was due to the influence of class I presents with phonologically regular full grade root, thus: *asy-á- $\rightarrow$ ásya-, *paśy-á- $\rightarrow$ páśya-, etc. on the model of * gacháti $\rightarrow$ gáchati, where $a<{ }^{*} n$ has been reanalysed as full grade (Saussure 1879: 174 [= Rec., 163]); ${ }^{23}$ cf. also Gonda 1951: 92 ("the accentual differentiation of the -ya-verbs was attended by a partial leaning towards other thematic rootaccented presents"); 1971: 91.

On the other hand, Delbrück (1897: 435f.) argued for the opposite development ('-ya- $\rightarrow$ -yá-); cf. also Kümmel in LIV 637, note 2 [ad got. paursjan* 'dürsten'] s.v. *ters-. ${ }^{24}$ No doubt, the system of -ya-presents was subject to a number of analogical accent shifts of both kinds ('-ya$\leftrightarrow-y a ́-)$, even within the historical period; see Section 4 on -ya-presents with fluctuating accentuation and Kulikov 2011 on the supposedly passive origin of -ingya-te (-ángya-te) 'move, stir' and trya-te 'move'.

The difference in accentuation between (middle) class IV presents and -yá-passives is clearly secondary. We can only speculate why the passive subclass has generalized the suffix accentuation (which probably was original), while non-passives have retracted accent to the root. This accent shift may have started in a few old non-passive -ya-presents, in which zero and full grade could not be distinguished (cf. mányate), or where the full grade was introduced instead of the phonetically impossible zero grade (as in padyate $\leftarrow^{* *} p d y a$ ate) or in order to avoid morphological opacity (nahyati/-te $\leftarrow{ }^{* *}$ ahyáti/-te $<{ }^{*}$ nhiátil-tai (?) or asyati/te $\leftarrow{ }^{*}$ siáti/-tai). ${ }^{25}$ The root accentuation could be introduced for such presents in accordance with Saussure's rule (reformulated by Kuryłowicz for -ya-presents, see above) and subsequently generalized for all non-passives.

\subsection{The genesis of accentuation of $-y a$-presents: a possible scenario}

A possible relative chronology of accent shifts in the Vedic middle -ya-presents can be summarized as follows:

itself be used predicatively", whereas causatives and -yá-passives are supposed to be derivatives from this noun. For a comprehensive survey of existing hypotheses, see also Kulikov 2011.

21 “... everybody knows the intimate connection between the -yá- class and the $4^{\text {th }}$ present-class".

22 Saussure (1879: 234 [= Rec., 219], with fn. 1) even assumed that the active -ya-present ranyáti (with the irregular suffix accentuation) might be a trace of the original accent placement in this present type.

${ }^{23}$ Essentially the same hypothesis was already proposed by Froehde (1881: 172), albeit in a less explicit form.

24 "Offenbar *tŕs-ie- mit verschobenem Akzent wie im Ved. (oder deutet dieser Fall auf grundsprachliches Alter des Wurzelakzents bei primären ie-Präsentien?)”.

${ }^{25}$ Cf. LIV 227, note 2 s.v. ${ }^{*}$ Hned $^{h}$ - and LIV 242f., note 4 s.v. ${ }^{*} h_{1} e s-~$. 


\section{Proto-Indo-Aryan}

I. Accent retraction

in non-passive -ya-presents.

Accentual differentiation

of -yá-passives and (middle)

non-passive -ya-presents

II. Accent shift

in the type mriyáte:

*Cŕ-ia- $\rightarrow$ Criyá-

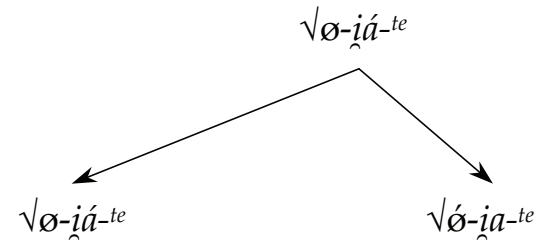

(e.g. hanyáte 'is killed')

(e.g. mányate 'thinks')

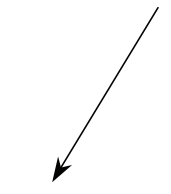

لø-iá-te

(hanyáte)

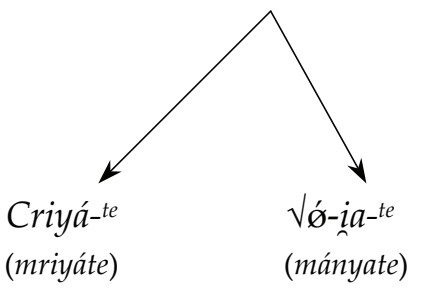

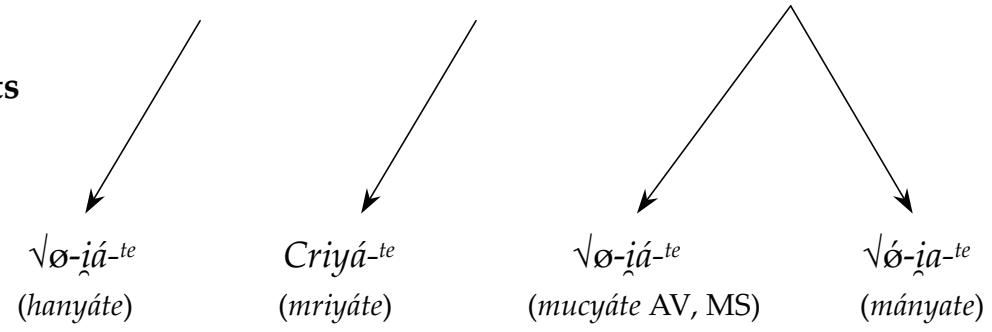

Alexei Kassian Institute of Linguistics of the Russian Academy of Sciences (Moscow)

Some considerations on Vedic-ya-presents

The paper by L. Kulikov consists of two parts: 1) detailed discussion upon the peculiarities of some specific Vedic verbal stems, and 2) reconstruction of the -ya-present pattern for Proto-Indo-Aryan. Below I will touch upon the second - comparative - portion of the paper (§5).

Kulikov discusses two functions of the Vedic -yasuffix: medial present tense of the $4^{\text {th }}$ class with nonpassive intransitive function, i.e. the $\sqrt{ }^{\prime}-y a^{-t e}$ pattern (however, the frequent active $\sqrt{ }^{\prime}-y a^{-t i}$ pattern is excluded from the analysis) and the regular passive forms of the $\sqrt{ }-y a^{-t e}$ pattern. The author concludes that the original Proto-Indo-Aryan pattern of the middle voice was ${ }^{*} \sqrt{ }-y a^{-t e}$, which later split into two accentual and semantic types. ${ }^{1}$

${ }^{1}$ Kulikov labels this proto-level as "Proto-Indo-Aryan", but, in fact, some OPers. and Avest. evidence may prove that the
The only explication of such a split proposed by Kulikov is J. Kuryłowicz's idea that non-passive mid-

grammaticalization of the $y a$-suffix as an exponent of the passive voice goes back to the Proto-Indo-Iranian level. On the contrary, if we reject OPers. and Avest. data, an accurate term should be "Proto-Vedic", not Proto-Indo-Aryan in general. On the other hand, the Dardic language Shina shows the same grammaticalized passive voice in -izh- $(=-i j-)$, Bailey 1924: 29 , Schmidt \& Kohistani 2008: $145 \mathrm{ff} ., 194 \mathrm{f}$. This fact should prove the Proto-IndoAryan antiquity of such a grammaticalization, if Shina $-i \underline{h}$ - does indeed contain *-ya- (as is suspected by V. A. Dybo, see his reply below, although I would rather suppose that Shina $-i \underline{h}$ - reflects an innovative formation in Dardic). Below, for the sake of convenience, I will use Kulikov's term "Proto-Indo-Aryan" in regard to the grammaticalized passive voice in $-y a-$.

In any case, it is important that such a grammaticalization is an inner Indo-Aryan (or Indo-Iranian) innovation. E.g., in the Balto-Slavic group (the closest linguistic relative of Indo-Iranian) i-praesentia normally seem to be associated with transitive or 